\title{
ATYPICAL GLANDULAR CELLS IN PAP SMEAR AS A PRIMARILY PRESENTATION OF OVARIAN SEROUS BORDERLINE TUMOR
}

\author{
DANIJELA JURIČ ${ }^{1}$, ANA BARIŠIĆ ${ }^{,}$, SANDA RAJHVAJN, VESNA MAHOVLIĆ ${ }^{1}$, \\ DAVOR PETROVIĆ ${ }^{1}$, MARIJA MACAN ${ }^{1}$ and FRANJO GRGIĆ ${ }^{2}$
}

${ }^{1}$ Department of Pathology and Cytology, University Hospital Center Zagreb, Zagreb, Croatia;

${ }^{2}$ Department of Gynecology and Obstetrics, University Hospital Center Zagreb, Zagreb, Croatia

\begin{abstract}
Summary
The Pap test is designed as a screening test to detect primarily carcinoma of the cervix and its precursors, most often of squamous type. Rarely atypical or malignant cells found in cervical smear can be indication for the existence of an extrauterine disease. We present a case of a 26 year old woman with very small asymptomatic ovarian bilateral borderline tumors whose diagnosis was triggered by finding of atypical glandular cells with psammoma bodies on Pap smear. She had a history of abnormal Pap smears and was admitted to our Hospital for colposcopy. Pap smear was taken and reported as atypical glandular cells (AGC) with psammoma bodies. Colposcopically directed biopsy along with an endocervical curettage showed no abnormalities as well as transvaginal ultrasound examination. Three months later control Pap smear confirmed AGC with psammoma bodies (suggestive of endometrial or serous origin), ultrasound showed the presence of indistinctive, hyperechoic mass $2 \mathrm{~cm}$ in diameter in the left ovary along with slightly elevated CA-125 and diagnostic hysteroscopy and laparoscopy was performed. At laparascopy, both ovaries had surface cauliflower like papillary projections measuring up to $3 \mathrm{~cm}$. A histological examination revealed bilateral serous borderline tumor.
\end{abstract}

KEY WORDS: Pap test, atypical glandular cells, psammoma bodies, serous borderline tumor

\section{INTRODUCTION}

Pap test remains one of the best cancer screening test used to detect precancerous and cancerous squamous lesions of the cervix. Although less sensitive in detecting cervical glandular lesions, rarely, HPV negative carcinomas of other sites can be found in Pap smear.

Serous borderline tumors/atypical proliferative serous tumors (SBT/APSTs) are non-invasive tumors that display greater epithelial proliferation and cytological atypia than benign serous tumors but less than low-grade serous carcinoma (LGSC)(1). APST often have scattered small foci of

Corresponding author: Danijela Jurič, Department of Pathology and Cytology, University Hospital Center Zagreb, Zagreb, Croatia, Petrova 13, 10000 Zagreb, Croatia. e-mail: danijela.juric20@gmail.com a micropapillary pattern $(<5 \mathrm{~mm}$ of confluence $)(2)$. Identification of extra-ovarian disease is critical since the most important predictor of adverse outcome is the presence of LGSC (invasive implants). APST occur in younger women, are present at an early stage, average size is $10 \mathrm{~cm}$, most behave in a benign fashion but a minority pursues an indolent course, some as long as 20 years; tumors may recur as SBT/APSTs or as LGSC(1).

\section{CASE REPORT}

A 26 year old female, married, nulliparous, was referred to the Department of Gynecology and Obstetrics University Hospital Center Zagreb, due to a three years history of abnormal Pap smears confirmed by biopsy two years earlier as high grade squamous intraepithelial lesion (HSIL). 
Gynecological examination presented no abnormality. Transvaginal ultrasound demonstrated polyp in cervical canal (dimensions $13 \times 5 \mathrm{~mm}$ ), otherwise no abnormalities were found. Pap smear was taken on the eight day of menstrual cycle and numerous groups of endometrial cells, both benign and atypical glandular cells not otherwise specified (AGC-NOS) of probably endometrial origin (Fig.1), along with psammoma bodies, and a few atypical squamous cells - cannot exclude HSIL (ASC-H) were detected. On colposcopy squamo-columnar junction was partially visible with major changes (area of dense aceto-white epithelium) and a colposcopically directed biopsy was taken, along with an endocervical curettage although endocervical polyp was not obtained. Histopathological examination showed no abnormalities.

Three months later in control Pap smear AGC-NOS with psammoma bodies were found on the clean background, suggestive of endometrial or serous origin (Fig.2), HPV test was negative and further investigation was proposed. Repeated ultrasound showed the presence of indistinctive, hyperechoic mass $2 \mathrm{~cm}$ in diameter in the left ovary. Oncological markers CA 15-3 and CA 19-9 were within normal limits, while CA 125 was slightly elevated to $63.21 \mathrm{U} / \mathrm{ml}$, not significant for a given age. In consultation with the gynecologist considering possible serous type of abnormal glandular cells (the same type that may be found in effusions of patients with serous type ovarian tumor) and ultrasound finding it was decided to perform diagnostic hysteroscopy and laparoscopy. At hysteroscopy no abnormalities were found but samples of endometrium were taken. At laparascopy, both ovaries had surface cauliflower like papillary projections measuring up to $3 \mathrm{~cm}$. Intraoperative peritoneal washing cytology was taken and a numerous papillary, trodimensional clusters of abnormal serous cells with psammoma bodies and ciliated cells were found, suggestive for serous borderline tumor (Fig.3). Intraoperative histology of the tumor was also suggestive of serous borderline tumor, and laparoscopy was converted to laparotomy. Deposits sized few millimeters were seen on omentum, pelvic peritoneum and rectosigmoidal serosal surface and all surgically visible changes were resected with the intention of preservation of the fertility. Partial omentectomy, bilateral ovarian wedge biopsy and total

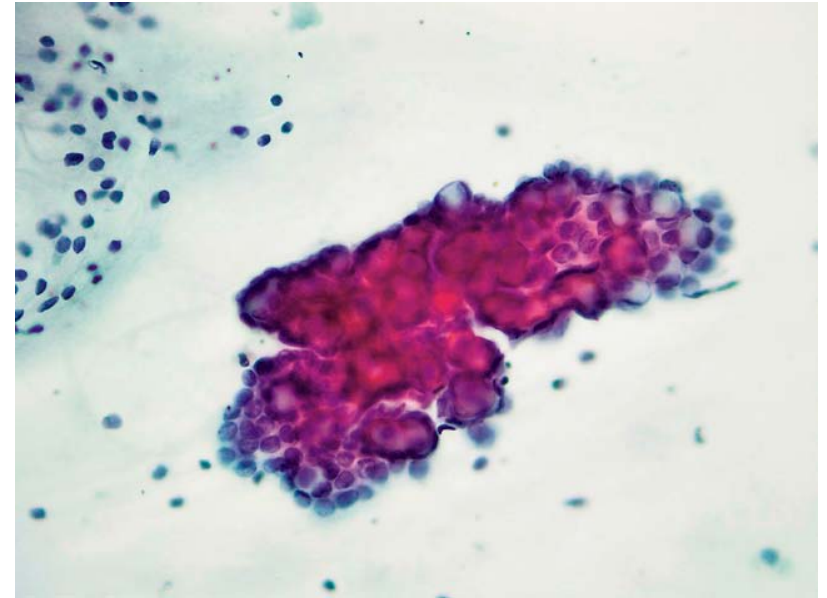

Figure 1. Pap smear showing psammoma bodies surrounded by atypical glandular cells in trodimensional papillary cluster (Papanicolaou stain, 400x)

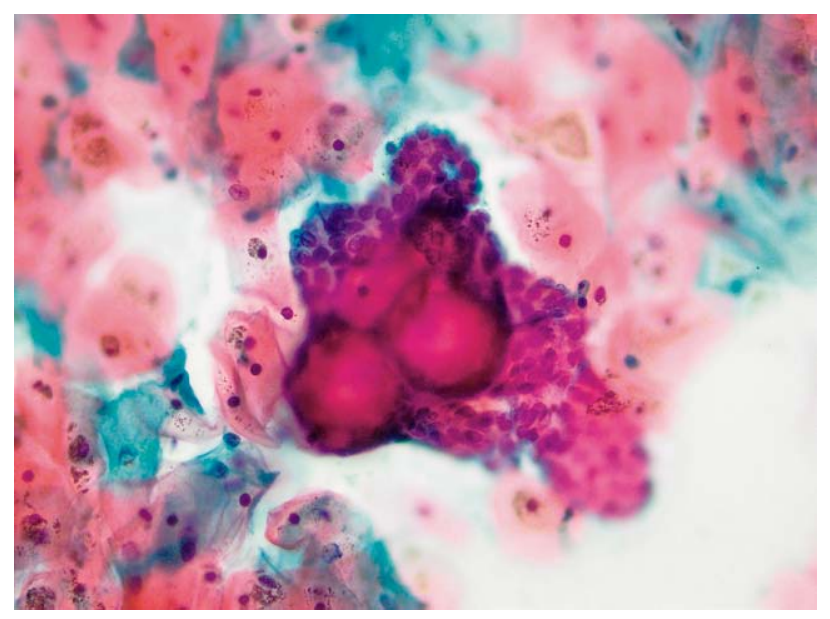

Figure 2. Pap smear showing psammoma bodies surrounded by atypical glandular cells in trodimensional papillary cluster $(\mathrm{Pa}-$ panicolaou stain, 400x)

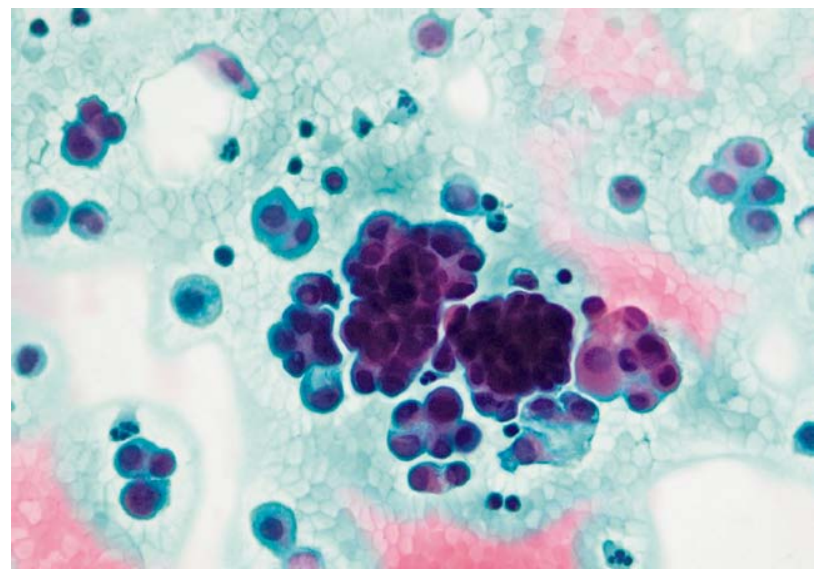

Figure 3. Positive peritoneal cytology (Papanicolaou 400x) 
pelvic peritonectomy were performed. Final histopathology reports were proliferative endometrium in endometrial biopsy specimens and bilateral atypical proliferative (borderline) serous tumor (micropapillary architecture) with noninvasive peritoneal implants and endosalpingiosis. Because of the young age of the patient and her fertility planning, careful follow-up was proposed. Second-look laparoscopy performed 18 months later did not reveal any visible changes, but histopathology confirmed recurrence of the disease on random biopsies of both ovaries. Considering the course of the disease a multidisciplinary team suggested total abdominal hysterectomy and bilateral salpingo-oophorectomy and patient agreed although she did not give birth. Final histopathology report confirmed the presence of borderline serous tumor on the right ovary. Patient remained disease-free three years after, and hormone replacement therapy was administered.

\section{DISCUSSION}

Though cervicovaginal cytology is neither a screening nor a diagnostic tool for ovarian or peritoneal tumors, numerous cases of initial presentation of ovarian or peritoneal carcinomas as adenocarcinoma or atypical glandular cells (AGC), often with psammoma bodies, have been reported(3). AGC is a rare finding in PAP smear ranging from $0,23 \%(4), 0,29 \%(5)$ to $0,41 \%(6)$. Clinical studies investigating the histological results for women with AGC findings most often encompassed a broad range of benign and reactive changes $(54,3 \%(4), 66,4 \%(6))$, precancerous squamous lesions $(6,2 \%(6), 18,4 \%(4))$, and cervical AIS $(1,8 \%$ (4), 2,4 (6)) are often found. Due to possibility of numerous malignant lesions diagnosed subsequent AGC finding like squamous cervical carcinoma $(0,2 \%(6), 3,1 \%(4))$, cervical adenocarcinoma $(3 \%(6), 5,8 \%(4))$, endometrial neoplasia $(8,2 \%(6)$, $14,8 \%(4))$, or even ovarian carcinoma $(0,6 \%(5)$, $0,6 \%(6), 1,3 \%(4))$, careful clinical investigation after AGC finding is recommended.

Malignant cells from extrauterine primaries may appear in a cervical cell sample in one of the three ways. The most common is direct extension from adjacent primaries (endometrium, rectum, bladder), less frequent lymphatic and/or hematogenous dissemination (gastrointestinal tract, breast, ovary) and finally exfoliation of cells from an ovarian tumor or ascites(7). Extrauterine cancers involving the abdominal peritoneum may shed and pass through the fallopian tubes and the uterine cavity to accumulate in the vaginal pool in the posterior fornix. Although not specific, the presence of large, atypical cells in trodimensional, papillary groups eventually with psammoma bodies suggests a Mullerian carcinoma (tuboovarian/peritoneal origin). The smear background is characteristically clean, free of tumor diathe$\operatorname{sis}(7)$.

The presence of psammoma bodies in Pap smear is extremely rare with an incidence of less than $0.001 \%(0,000005 \%(8), 0,009 \%(9), 0,0029 \%(10)$, $0,006 \%(11))$. Psammoma bodies in Pap smear should alert to the possibility of a papillary serous ovarian carcinoma, however it should be born in mind that psammoma bodies may be seen in cervicovaginal cell sample more often with benign conditions than with malignancies (endosalpingiosis, women with IUD, etc.)(10,12). Patients with psammoma bodies have a wide range of associated malignancy or ovarian borderline tumor in different series $(0 \%(11), 22 \%(8), 33 \%(10), 50 \%(9))$. Nevertheless, due to possibility of serous type of carcinoma, careful clinical investigation is recommended after psammoma bodies finding in Pap smear(11).

Approximately one half of the SBT are stage Ia and $\mathrm{Ib}$, but positive peritoneal washing is expected in cases with peritoneal implants(13). Other authors report the same cell type with psammoma bodies in different samples like in our case(14). Nevertheless one must always be careful in such cases because peritoneal washing cytology of SBT can mimic benign (endosalpingiosis, serous papillary cystadenoma) as well as malignant condition (LGSC) (15).

The present case describes rare case of a borderline serous tumor detected by Pap smear. To our knowledge there are only six described cases in literature of SBT detected by Pap smear as the first presentation of the disease $(8,14,16,17,18,19)$ and one case of an ovarian seromucinous borderline tumor recurrence(20). Psammoma bodies were found in five of described SBT cases $(8,14,16,18,19)$, two of them with psammoma bodies only $(8,14)$ and others with abnormal glandular cells like in our case. 


\section{CONCLUSION}

Exfoliative cytology is a valuable method in the early detection of cervical abnormalities. Regardless of its primary purpose, in rare cases it can detect tumors of other locations. Despite the fact that Pap smear often discover extracervical abnormalities, most often endometrial, ovarian and peritoneal malignances are sometimes recognized as well. This study supports the extant literature, confirming that cervicovaginal cytology may be trigger for detection of ovarian tumors, even borderline tumors. Our case, as well as preceding literature, has shown that cervicovaginal cytology may be beneficial in the initial diagnosis of other tumors.

\section{REFERENCES}

1. Longacre TA, Wells M. Serous tumours. In: Kurman RJ, Carcangiu ML, Herrington CS, Young RH, editors. WHO classification of tumours of female reproductive organs. Lyon: IARC; 2014. p.15-24.

2. Seidman JD, Cho KR, Ronnett BM, Kurman RJ. Surface epithelial tumors of the ovary. In: Kurman RJ, Ellenson LH, Ronnett BM, editors. Blaustein's pathology of the female genital tract sixth edition. New York: Springer; 2011. p.679-784.

3. Nwanodi O, Choi C, Khulpateea N. Cervicovaginal cytology and diagnosis of ovarian or peritoneal cancer: case report and literature review. Arch Gynecol Obstet. 2008;277:171-4.

4. Dhamne S, Soundars E, Zarrin-Khameh N. Pathologic findings in women with atypical glandular cells on Pap test. J Am Soc Cytopathol. 2016;5:50-5.

5. Schnatz PF, Guile M, O'sullivan DM, et al. Clinical significance of atypical glandular cells on cervical cytology. Obstet Gynecol 2006;107:701-8.

6. Zhao C, Florea A, Onisko A, Austin RM. Histologic follow up results in 662 patients with Pap test findings of atypical glandular cells: Results from a large academic women's hospital laboratory employing sensitive screening methods. Gynecol Oncol 2009;114: 383-9.

7. Tabbara SO, Khalbuss WE. Other malignant neoplasms. In: Nayar R, Wilbur D, editors. The Bethesda system for reporting cervical cytology: definitions, criteria and explanatory notes. New York: Springer; 2015. p.241-261.
8. Nicklin JL, Perrin L, Obermair A, McConachie I, Cominos $\mathrm{D}$. The significance of psammoma bodies on cervical cytology smears. Gynecol Oncol. 2001;83:6-9.

9. Parkash V, Chacho MS. Psammoma bodies in cervicovaginal smears: incidence and significance. Diagn $\mathrm{Cy}-$ topathol. 2002;26:81-6.

10. Pusiol T, Parolari AM, Piscioli I, Morelli L, Del Nonno F, Licci S. Prevalence and significance of psammoma bodies in cervicovaginal smears in a cervical cancer screening program with emphasis on a case of primary bilateral ovarian psammocarcinoma. Cytojournal. 2008;5:7.

11. Muntz HG, Goff BA, McGonigle K, Isacson C. The significance of psammoma bodies in screening cervical cytologic smears. Am J Obstet Gynecol. 2003;188: 1609-12.

12. Koss LG. Tumors of the ovary and fallopian tube. In: Koss LG, Melamed MR, editors. Koss' diagnostic cytology and its histopathologic bases, 5th Edition. Philadelphia: Lippincott Williams \& Wilkins; 2006. p.491-513

13. Chen X, Fang C, Zhu T, Zhang P, Yu A, Wang S. Identification of factors that impact recurrence in patients with borderline ovarian tumors. J Ovarian Res. 2017; 10:23.

14. Qazi FM, Geisinger KR, Barrett RJ, Hopkins MB, Holleman IL: Cervicovaginal psammoma bodies: the initial presentation of the ovarian borderline tumor. Arch Pathol Lab Med 1988;112:564-6.

15. Rajhvajn S, Mahovlić V. Serous ovarian tumors, cytological findings. In: Schmitt F, editor. Cytopathology. Encyclopedia of pathology. Cham: Springer; 2017. p.459-63.

16. Ahsan S, Manyonda I, Spencer T, Ratcliffe N. Psammoma bodies in a cervical smear in association with borderline ovarian epithelial malignancy. J Pak Med Assoc. 1998;48:52-3.

17. Tepeoğlu M, Özen Ö, Ayhan A: Ovarian serous borderline tumor detected by conventional Papanicolaou smear: A case report. Acta Cytologica 2013;57:96-9.

18. Athavale RD, Chia KV. Psammoma bodies on postmenopausal cervical smear--a rare sinister finding. J Obstet Gynaecol. 2002;22:328-9.

19. Zhang Y, Selvaggi SM. Significance of psammoma bodies on a cervical sample from an asymptomatic woman. Diagn Cytopathol. 2003;29:339-40.

20. Hayashi H, Taniguchi S, Kurihara S, Hachisuga K, Fukuda S, Inada C, Shimao Y, Marutsuka K, Shimamoto T. Pelvic recurrence of an ovarian seromucinous borderline tumor detected by vaginal cytology: A case report and review of the literature. Diagn Cytopathol. 2016;44:912-6. 


\section{Sažetak \\ ATIPIČNE GLANDULARNE STANICE U PAPA TESTU KAO PRIMARNA PREZENTACIJA SEROZNOG BORDERLINE TUMORA JAJNIKA}

\section{Jurič, A. Barišić, S. Rajhvajn, V. Mahovlić, D. Petrović, M. Macan, F. Grgić}

Papa test je test probira primarno namijenjen za rano otkrivanje karcinoma cerviksa i njegovih prekursora, najčešće pločastog tipa. Rijetko nalaz atipičnih ili malignih stanica u Papa testu može biti prvi znak tumora ekstrauterinog porijekla. $\mathrm{U}$ ovom radu prikazujemo slučaj 26 godišnje pacijentice s vrlo malim asimptomatskim bilateralnim borderline tumorima jajnika čija je dijagnoza pokrenuta nalazom atipičnih žljezdanih stanica sa psamomskim tjelešcima u Papa testu. Pacijentica je upućena u našu bolnicu na kolposkopiju radi abnormalnih nalaza Papa testa. Kod nas uzeti Papa test pokazao je atipične glandularne stanice (AGC) sa psamomskim tjelešcima. Kolposkopski vođena biopsija i endocervikalni ekskohleat nisu pokazali abnormalnosti, kao ni transvaginalni ultrazvučni pregled. Tri mjeseca kasnije ponovljeni Papa test potvrđuje AGC sa psamomskim tjelešcima (porijeklo endometralno ili serozno), ultrazvučni nalaz opisuje uz lijevi jajnik nejasnu hiperehogenu tvorbu promjera $2 \mathrm{~cm}$, uz blago povišeni CA 125 zbog čega je učinjena dijagnostička histeroskopija i laparoskopija. Na operaciji su nađeni jajnici obostrano s tumorskim tvorbama karfiolastog izgleda veličine do $3 \mathrm{~cm}$. Patohistološki je potvrđen serozni borderline tumor oba jajnika.

KLJUČNE RIJEČI: Papa test, atipične glandularne stanice, psamomska tjelešca, serozni borderline tumor 